Urol. int. 1980;35:I-VI

\title{
Contents, Vol. 35, 1980
}

\section{No. 1}

Original Paper

Motor Urge Incontinence: Diagnosis and Treatment

Gaudenz, R. and Weil, A 1

Change of Total and Prostatic Serum Acid Phosphatase Levels following Hyperglycemic

Treatment in Patients with Prostatic Carcinoma

Ishibe, $\mathrm{T} \quad 13$

Beeinflussung einer durch Antigenvorbehandlung induzierten Sensibilisierung xenogener

Transplantat-empfänger durch Azathioprin und Prednisolon

Prange, C.H.; Bach, D., and Kessler, M 20

Dip-Slide in Patients at High Risk of Urinary Tract Infection

Bonadio, M 24

Neue Aspekte der Harnblasenphysiologie

Festge, O.-A 28

Serum-Ionized Calcium as a Diagnostic Tool in Hypercalciuria

Iguchi, M.; Kohri, K.; Akiyama, T.; Yachiku, S., and Kurita, T

Kidney and Bladder Pulsating Activities during Radioisotope Renogram by Computer Data

Analysis

Ram, M.; Graber, P.; Donath, A., and Hessler, D 42

In vivo Labelling of Alpha-Adrenoceptor-Binding Sites and Membrane-Bound Extraneuronal Transport Sites in the Urinary Bladder of the Rat by H-ST-1059 and 5/8Phentolamine. An Autora'diographic Study

Jonas, D.; Moritz, F.; Jenner, S., and Baumgarten, H.G

Urodynamic Analysis of Urethral, Vesical and Perivesical Pressure Distribution in the Healthy Female

Constantinou, C.E. and Govan, D.E 63

Möglichkeiten der Krebsvorsorge der Blase und der ableitenden Harnwege auf der Basis einer automatisierten Urinzytologieauswertung. Vorläufige Mitteilung über erste Ergebnisse und Erfahrungen mit einem hochauflösenden zytologischen Messsystem

Aeikens, B 73

No. 2

Changes in Flow Resistance in Kidney Vessels of Dogs by Hypothermic Hyperosmotic

Perfusion

Ruedas, G 81

Comparative Light and Electron Microscopic Study of the Human, Dog and Rat Prostate. An Approach

to an Experimental Model for Human Benign Prostatic Hyperplasia (Light and Electron

Microscopic

Analysis) - a Review 
Bartsch, G. and Rohr, H.P 91

Modifizierung der Primärabstossung xenogener Nierentransplantate durch Anti-Donor-

Lymphozyten-

Globulin

Prange, C.H.; Kessler, M. und Bach, D 105

IV

Contents

The Effect of in situ Isolated Perfusion of Experimental Renal Tumors with Cytotoxic Agents in High Concentration. An Experimental Contribution to the Therapeutic Approach to Bilateral Nephroblastomas

Asbach, H.W. and Bersch, W 112

Effects of Cyproterone Acetate on Experimentally Induced Canine Prostatic Hyperplasia. A Morphological and Histochemical Study

Tunn, U.; Senge, T., Schenck, B., and Neumann, F 125

Activation of the Renal Pressure System following Severe Hypotension and Its Pathophysiologic Significance

Schilling, A 141

Zur Reintervention nach Ureterozystoneostomie unter besonderer Berücksichtigung des

Ureterersatzes durch eine Ileumschlinge

Rothauge, C.F.; Pust, R. und Weidner, W 146

The Endocrine Background of Human Renal Cell Carcinoma. V. Binding of the Highly Potent Androgen Methyltrienolone (R 1881) by Tumour Cytosol

Bojar, H.; Maar, H., and Staib, W 154

No. 3

Hydronephrotic Alterations in Calyceal and Renal Pelvic Pacemaker Function of the in vitro Pyeloure-teral System

Mensah-Dwumah, M.; Djurhuus, J.C., and Constantinou, C.E 161

A Urodynamic Study of Cauda Equina Syndrome due to Lumbar Disc Herniation

Nielsen, B.; Nully, M. de; Schmidt, K., and Hansen, R.I 167

13,14-Dihydro-15-keto-prostaglandin F2 $\alpha$ in Patients with Urogenital Tumors

Dunzendorfer, U.; Zahradnik, H.P., and Gerster, K 171

Urodynamic Response of Unstable Bladder to Flavoxate

Zanollo, A. and Catanzaro, F 176

Spontaneous Phasic Activity of the Detrusor. A Cause of Uninhibited Contractions in Unstable

Bladders?

Laval, K.-U. and Lutzeyer, W182

Noradrenergic Innvervation of the Human Bladder in Neurogenic Dysfunction

Nordling, J.; Christensen, B., and Gosling, J.A 188

Androgenstoffwechsel im Prostatakarzinom: 3-Hydroxysteroid-Dehydrogenase-Aktivität in

Abhängigkeit vom Tumordifferenzierungsgrad

Jacobi, G.H. und Altwein, J.E194

Renovascular Hypertension in Children

Menezes de Goes, G.; Arap, S., and Dénez, F.T 206

Biochemical and Electrophoretic Properties of Acid Phosphatase Isozymes and Their

Distribution in Cell Functions from Neoplastic Prostatic Tissues

Fischer, D.R. and Gevers, W 216 
Comparative Study of the Periurethral and Perianal Parts of the Human Levator ani Muscle Critchley, H.O.D.; Dixon, J.S., and Gosling, J.A 226

Zur Klinik des Prostatakarzinoms unter Berücksichtigung zyto- und histomorphologischer

Befunde

Stöber, U. und Schnaidt, U 233

Book Review 240

Contents

$\mathrm{V}$

No. 4

Morphologische Untersuchungen und morphometrische Messungen am Nephron einseitig harnleiter-ligierter Ratten

Aeikens, B.; Haenschke, H.-J. und Neumann, A 241

Effect of Prolactin and Testosterone Administration on the Maintenance of Ventral Prostate

Transplants into Intact or Gonadectomized Male and Female Syngeneic Rats

Edwards, W.D. and Thomas, J.A 251

Nierenadenome: Dignität, Klinik und Therapie

Kuhn, F.-P. und Altwein, J.E 258

Ultrastructural Visualization of Concanavalin A Binding Receptor Sites in Neoplastic and Non-

Neoplastic Transitional Cell Epithelium of the Human Urinary Bladder

Kjaergaard, J.; Starklint, H., and Bierring, F 271

Perkutane Punktion zystischer Raumforderungen der Niere zur Diagnostik und Therapie

Bach, D.; Weissbach, L.; GrauthofГ, H. und Lackner, K.J 281

Evaluation of Human Chorionic Gonadotropin- $\beta$ Levels in Prostatic Carcinoma

Menon, M. and Stefani, S.S 291

Transurethrale Resektionstechnik bei Hochdruckirrigation. Die Arbeitsweise mit dem

Zentralhahn

Mauermayer, W. und Schütz, W 294

Quantifying Female Incontinence with Particular Reference to the Urilos System

Wilson, P.D.; Al Samarrai, M.T., and Brown, A.D.G 298

Oxalate Urolithiasis: Significance of Serum and Urinary Oxalate

Butz, M. and Kohlbecker, G 303

No. 5

Dietary Influence on Serum and Urinary Oxalate in Healthy Subjects and Oxalate Stone Formers

Butz, M.; Hoffmann, H., and Kohlbecker, G 309

Carcinoma in situ of the Renal Pelvis after Cystectomy. A Case Report Including Comments

concerning Diagnostic Procedures and Surgical Treatment (With 1 Color Plate)

Hellsten, S.; Glifberg, I.; Lindholm, K.; Lindholm, C.-E.; Ogiwara, T., and Wehlin, L 316

Psychogenic Voiding Patterns

Palmtag, H. and Riedasch, G 321

Interrelations of PTH, cAMP, Creatinine and Uric Acid in Nephrectomized Patients under DNA or PTH Application

Dunzendorfer, U.; Ohlenschläger, G., and Schmidt-Gayk, H

Early Events in Stricture Formation in the Guinea Pig Urethra

Scott, T.M. and Foote, J 334

Chemische Induktion transplantabler Harnblasenurothelkarzinome des Hundes

Harzmann, R.; Gericke, D.; Altenähr, E. und Bichler, K.-H 340 
Structure of Trabeculated Detrusor Smooth Muscle in Cases of Prostatic Hypertrophy Gosling, J.A. and Dixon, J.S 351

Male Stress Incontinence. Diagnostic Work-Up and Therapeutic Considerations

ThürofT, J.W.; Petri, E., and Jonas, U 356

Urodynamic Effects of Intravenous Benzilonium Bromide in Healthy Subjects

Nyman, C.R 363

VI Contents

C-Peptide, Testosterone, Estrogen, Cortisol and Zinc in Patients with Benign Hyperplasia of the Prostate

Dunzendorfer, U. and Drahovsky, D 369

Fallbericht: Perkutane Nephrostomie und instrumentelle Steinentfernung in Lokalanästhesie Thüroff, J.W. und Hutschenreiter, G 375

Announcement $\quad 380$

No. 6

Bioverfügbarkeit von Cyproteronacetat nach oraler und intramuskulärer Applikation bei

Männern

Becker, H.; Düsterberg, B. und Klosterhalfen, H 381

Vesico-Uterine Fistula following Caesarean Section

Henriksen, H.M 386

A Simple Method of Predicting Progression of Polycystic Kidney Disease by $99 \mathrm{mTc}-$

Dimercaptosuccinic Acid Renal Scintigraphy

Kawamura, J.; Ito, H.; Sawanishi, K., and Yoshida, $0 \quad 388$

Der Einfluss vollständig ligierter Harnleiter auf die Tubuluszellregeneration nach Entstauung durch Ureterozystoneostomie

Stöber, U. und Aeikens, B 395

Crossed Ureteral Ectopia with Solitary Kidney

Isorna Martinez de la Riva, S.; Santiago, A.; Barberena, J.; Romeo, A., and Sebastian, J.L404

Etiologic Factors in Peyronie's Disease

Hinman, F. Jr 407

Sexual Dysfunction Associated with Urinary Incontinence

Sutherst, J. and Brown, M 414

Absence of L-Histidine Ammonia Lyase and Histidine Imidazole Metabolites in Human

Adenomatous Prostate

Sande, M. van and Van Camp, K 417

Nachweis harnstoffspaltender Keime im Urin bei Steinpatienten

Bichler, K.-H.; Behrendt, W.A.; Haussmann, A.; Schulze, H.S. und Harzmann, R 421

Telemetric Urodynamic Investigations in Normal Males

Thüroff, J.W.; Jonas, U.; Frohneberg, D.; Petri, E., and Hohenfellner, R 432

Karyometrie zur Verlaufskontrolle beim hormonbehandelten Prostatakarzinom

Stöber, U. und Aeikens, B 435

Book Review 444

Author Index 445

Subject Index 447 